\title{
ANALYSIS OF FINANCIAL STABILITY OF COMPANIES WITH THE USE OF IMITATION MODELING OF CASH FLOWS
}

\author{
Ruslan Sagitov ${ }^{1}$ \\ Alexey Kirpikov ${ }^{2}$
}

\begin{abstract}
Most modern methods of retrospective assessment of financial stability of companies have significant internal contradictions that hinder their productive use in the process of scientific research and practical activities of economic entities. A coefficient analysis of the financial condition is accompanied by difficulty in determining the normative values of indicators that would take into account the industry and individual characteristics of the organization. The use of regression analysis requires a significant array of historical data and the selection of key indicators that do not have a high level of correlation. According to the authors, the forecasting of cash flows using simulation methods has a significant potential for predicting financial stability. The empirical basis of the study was formed by indicators of cash flow
\end{abstract}

budgets, information presented in annual reports, and also published in the media by one of the largest petrochemical companies in the Russian Federation in retrospect from 2011 to 2018 . The tools of simulation modeling assumed the use of a uniform distribution law of a random variable, the justification of the boundaries of the change in the initial variables with a confidence level of $95 \%$ was based on the provisions of the $\mathrm{VaR}$ method. The conceptual basis of the simulation model was determined by an algorithm for formalizing the dependence of the components of cash flows on current financial and investment activities with a resulting indicator, which was played by the free cash balance at the end of the forecast period. According to the authors, improving the quality of the meaningful interpretation of the results implies an

\footnotetext{
${ }^{1}$ Kazan Federal University, Institute of management, economics and finance, Kazan, 420008, Russia. e-mail: axelgreat@ mail.ru. Tel.: +7 9047650500

${ }^{2}$ Kazan Federal University, Institute of management, economics and finance, Kazan, 420008, Russia. e-mail: axelgreat@ mail.ru. Tel.: +7 9047650500
} 
independent statistical evaluation and visual presentation of the results of experiments that demonstrated a positive and negative level of effectiveness of financial and economic activities.

Keywords: financial stability, simulation modeling, cash flows, VaR technique.

\section{Introduction}

The intensification of the processes of economic globalization taking place under continuous fluctuations in the state of international markets determine the inevitability of a collision of companies with new challenges. The most important structural element of the strategic management tasks of the enterprise is the forecasting of cash flows, which allows us to assess the growth factors and financial risks of the enterprise in order to increase its financial stability. The forecast assessment toolkit is quite extensive; it includes methods of expert assessments, approaches to constructing stochastic dependencies. We believe that the use of simulation technology to a greater extent than other formalized approaches allows us to implement a
250

parametric assessment of significant factors and circumstances that may lead to a decrease in expected results compared to predicted ones.

\section{Methods}

The fundamental principles of the theory of analytical assessment of financial stability have been significantly developed in modern economic science. At the same time, the diversity of methodological approaches, on the one hand, reflects a significant discreteness of their content, and, on the other hand, demonstrates an orientation toward describing the current financial situation. According to individual researchers, financial stability, explained through the concepts of liquidity and solvency, implies the use of financial statements as input, reflecting financial stability on a particular day - at the end of a fiscal year [2]. The disadvantages of a retrospective assessment of the financial condition of the organization determine the object need for the development of applied aspects of the application of economic and mathematical modeling tools, in which a special role is played by scenario forecasting algorithms, which make it 
possible to increase the efficiency of managerial decisions under uncertainty $[5,8]$. The scientific work reflected econometric algorithms for the implementation of the Monte Carlo model, providing for the formation of an array of predictive estimates of the resulting indicator using the uniform distribution law of a random variable [6,7]. A generalization of the results of scientific research indicates that an organized system of cash flow planning provides an economic entity with the opportunity to effectively manage its financial stability [3]. In this regard, the components of the model are the components of the company's cash flows for current, financial, and investment activities.

Simulation was carried out in several stages:

1. The formation of the source data for the construction of simulation experiments based on the cash flow budget, formalization of the relationship between the model variables and the resulting indicators.

2. Justification of the boundaries of the range of variation of the model variables.
3. Selection of the law of distribution of a random variable to build an array of simulation experiments.

4. Scenario forecasting of the resulting indicators of the model and their meaningful interpretation using indicators of descriptive statistics.

At the first stage of the study, the task was to prepare the initial data necessary for conducting simulation experiments. In this work, we used the indicators of cash flow budgets of one of the largest domestic petrochemical companies formed during the period from 2011 to 2018, information on the structure of products in value and kind expressed in the annual reports of the company, and a number of auxiliary corporate data $[9,10]$.

The choice of the object of study is due to the key importance of petrochemical enterprises for the national economy, as well as the need for an economic assessment of changes in the financial stability of companies under the influence of a combination of factors of the external and internal environment.

To determine the boundaries of the intervals, it is advisable to use the VaR technique. Currently, VaR is a 
leading indicator of portfolio investment risk assessment but it can be successfully applied in alternative areas of economic research $[1,4]$. VaR models are based on a statistical evaluation of the distribution law of a variable. In our study, we used this technique to determine the left and right quantiles of the studied indicators. In statistics, quantile shall mean the value of the Gauss function with respect to the given parameters, at which the function will not exceed the value with a given probability. In traditional methods of analysis, values whose values are located at $90 \%, 95 \%$, and $99 \%$ are taken as the level of probability. When calculating the quantiles, the authors used a probability level of $95 \%$. To calculate the quantiles, the standard deviations and average values of the indicators were determined.

The next structural element of the study was the choice of the algorithm for the formation of simulation experiments. In this work, the authors propose to use the uniform distribution law of a random variable, implemented in the conditions of automated data processing using built-in functions that allow getting a random number from a given interval of variable variation.

The simulation model has found its practical implementation in the framework of 1000 simulation experiments. We shall consider the results of simulation in the context of the current investment and financial activities of the company.

Table 1 presents data on revenues from the current activities of the enterprise. The current activities of the organization are associated with the production and sale of products that provide the bulk of its income. Considering the fact that revenue generated by contracts concluded in the forecast period has a variable value due to fluctuations in natural sales volumes and selling prices, it is logical to separate it from revenue received from contracts of previous periods. The specific gravity of paid receivables, considered as an independent variable in the model, also has a significant effect on revenue. The range of indicators shown in Table 1 was obtained using the VaR technique.

Table 1:Revenues from the current activities of the company, thousand rubles

\begin{tabular}{|l|l|l|}
\hline & Variation range & Simulation experiments \\
\hline
\end{tabular}


Periódico do Núcleo de Estudos e Pesquisas sobre Gênero e Direito Centro de Ciências Jurídicas - Universidade Federal da Paraíba V. 8 - № 06 - Ano 2019 - Special Edition ISSN | 2179-7137 | http://periodicos.ufpb.br/ojs2/index.php/ged/index

\begin{tabular}{|c|c|c|c|c|c|}
\hline $\begin{array}{l}\text { Indicato } \\
\mathrm{r}\end{array}$ & in. & $\begin{array}{ll} & \mathrm{m} \\
\mathrm{ax} . & \end{array}$ & 1 & 2 & 00 \\
\hline $\begin{array}{l}\text { 1. Unit } \\
\text { price (rubles) }\end{array}$ & & & & & \\
\hline $\begin{array}{l}1.1 \\
\text { Rubbers }\end{array}$ & 643 & $5081^{11}$ & $\begin{array}{r}8 \\
7964\end{array}$ & $\begin{array}{r}8 \\
7912\end{array}$ & $\begin{array}{r}89 \\
061\end{array}$ \\
\hline $\begin{array}{l}\text { 1.2. } \\
\text { Plastics }\end{array}$ & $\begin{array}{r}46 \\
454\end{array}$ & $719^{89}$ & 5 & $\begin{array}{r}7 \\
5597\end{array}$ & $\begin{array}{r}89 \\
558\end{array}$ \\
\hline $\begin{array}{l}\text { 1.3. } \\
\text { Polyesters }\end{array}$ & $\begin{array}{r}58 \\
667\end{array}$ & 108 & $\begin{array}{r}7 \\
0814\end{array}$ & $\begin{array}{r}8 \\
2127\end{array}$ & $514^{81}$ \\
\hline $\begin{array}{l}\text { 1.4. } \\
\text { Monoethylene } \\
\text { glycol }\end{array}$ & $816^{35}$ & 586 & $5319^{4}$ & $4015^{5}$ & $115^{36}$ \\
\hline $\begin{array}{l}1.5 . \\
\text { Neonols }\end{array}$ & 91 & $\begin{array}{r}88 \\
640\end{array}$ & $\begin{array}{r}4 \\
3451\end{array}$ & $\begin{array}{r}8 \\
6278\end{array}$ & $\begin{array}{r}50 \\
665\end{array}$ \\
\hline $\begin{array}{l}1.6 . \\
\text { Ethylene }\end{array}$ & $816^{2}$ & $\begin{array}{l}40 \\
785\end{array}$ & $7460^{2}$ & $\begin{array}{r}9 \\
873\end{array}$ & $889^{20}$ \\
\hline Styrene & $609^{4}$ & $984^{79}$ & $211^{9}$ & $0825^{2}$ & 163 \\
\hline $\begin{array}{ll} & 1.8 . \\
\text { Other } & \end{array}$ & 340 & 968 & $2327^{1}$ & 1129 & 708 \\
\hline $\begin{array}{l}\text { 2. The } \\
\text { amount of } \\
\text { products sold } \\
\text { (thousand tones) }\end{array}$ & & & & & \\
\hline $\begin{array}{l}2.1 \\
\text { Rubbers }\end{array}$ & $6^{53}$ & $5^{73}$ & 92 & 86 & 55 \\
\hline $\begin{array}{l}2.2 . \\
\text { Plastics }\end{array}$ & $\begin{array}{ll} & 58 \\
2 & \end{array}$ & $\begin{array}{l}75 \\
4\end{array}$ & 69 & $\begin{array}{ll} & 6 \\
& \end{array}$ & $\begin{array}{ll} & 64 \\
9 & \end{array}$ \\
\hline $\begin{array}{l}2.3 . \\
\text { Polyesters }\end{array}$ & 82 & 87 & 8 & 6 & 85 \\
\hline
\end{tabular}




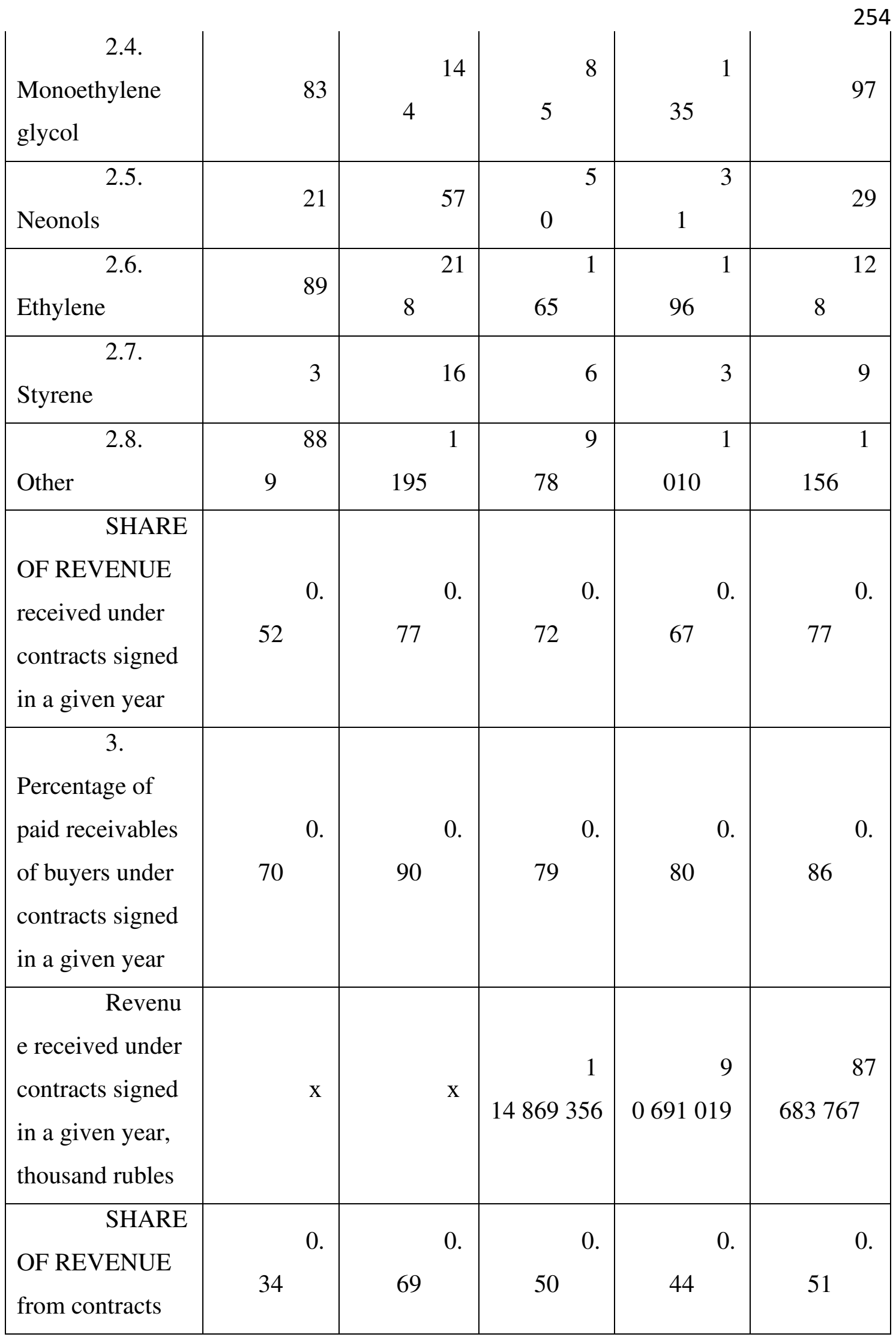




\begin{tabular}{|c|c|c|c|c|c|}
\hline $\begin{array}{l}\text { signed in } \\
\text { previous periods }\end{array}$ & & & & & 2 \\
\hline $\begin{array}{l}\text { 4. } \\
\text { Percentage of } \\
\text { paid receivables } \\
\text { of buyers under } \\
\text { contracts signed } \\
\text { in previous } \\
\text { periods }\end{array}$ & 84 & 96 & 95 & 89 & 90 \\
\hline $\begin{array}{l}\text { REVEN } \\
\text { UE from } \\
\text { contracts signed } \\
\text { in previous } \\
\text { periods }\end{array}$ & $\mathrm{x}$ & I & $\begin{array}{r}9 \\
5926413\end{array}$ & $\begin{array}{r}6 \\
6258588\end{array}$ & $\begin{array}{r}60 \\
777483\end{array}$ \\
\hline $\begin{array}{l}\text { TOTAL } \\
\text { INCOME }\end{array}$ & $\mathrm{X}$ & $Y$ & $\begin{array}{r}2 \\
10795769\end{array}$ & $\begin{array}{r}1 \\
56949607\end{array}$ & $\begin{array}{r}14 \\
8461250\end{array}$ \\
\hline
\end{tabular}

The structure of expenses for current activities includes payments to suppliers (contractors) for raw materials, materials, work, services, remuneration of employees, income tax, and other payments.

Next, we shall consider the investment activity of the company, which reflects the receipt and use of funds associated with the acquisition, sale of long-term assets. The result is net cash flow from investing activities.

Table 2 presents data on the investment activities of the company.

Table 2:Investment activity of the company, thousand rubles

\begin{tabular}{|c|c|c|c|c|c|}
\hline \multirow{2}{*}{$\begin{array}{l}\text { Indica } \\
\text { tor }\end{array}$} & \multicolumn{2}{|c|}{ Variation range } & \multicolumn{3}{|c|}{ Simulation experiments } \\
\hline & in. & $\begin{array}{l}\mathrm{m} \\
\mathrm{ax} .\end{array}$ & 1 & 2 & 00 \\
\hline
\end{tabular}


Periódico do Núcleo de Estudos e Pesquisas sobre Gênero e Direito Centro de Ciências Jurídicas - Universidade Federal da Paraíba V. 8 - № 06 - Ano 2019 - Special Edition ISSN | 2179-7137 | http://periodicos.ufpb.br/ojs2/index.php/ged/index

\begin{tabular}{|c|c|c|c|c|c|}
\hline $\begin{array}{l}\text { Inco } \\
\text { mes from the } \\
\text { sale of non- } \\
\text { current assets } \\
\text { (excluding } \\
\text { financial } \\
\text { investments) }\end{array}$ & 164 & $5650^{18}$ & 920 & $\begin{array}{r}88 \\
403\end{array}$ & $3003^{14}$ \\
\hline $\begin{array}{l}\text { Inco } \\
\text { me from the } \\
\text { sale of shares } \\
\text { of other } \\
\text { organizations } \\
\text { (shares) }\end{array}$ & 00 & 1083 & 1468 & $\begin{array}{r}48 \\
4349\end{array}$ & $\begin{array}{r}46 \\
5707^{4}\end{array}$ \\
\hline $\begin{array}{l}\text { Inco } \\
\text { me from the } \\
\text { return of } \\
\text { loans, from the } \\
\text { sale of debt } \\
\text { securities }\end{array}$ & 579 & $\begin{array}{r}7 \\
773447\end{array}$ & $\begin{array}{r}1 \\
725088\end{array}$ & $\begin{array}{r}4 \\
182869\end{array}$ & $\begin{array}{r}5 \\
842583\end{array}$ \\
\hline $\begin{array}{l}\text { Inco } \\
\text { me of } \\
\text { dividends and } \\
\text { similar income } \\
\text { from equity } \\
\text { participation } \\
\text { in other } \\
\text { organizations }\end{array}$ & 7669 & $\begin{array}{r}1 \\
784764\end{array}$ & $\begin{array}{r}1 \\
529617\end{array}$ & $\begin{array}{r}1 \\
014596\end{array}$ & $\begin{array}{r}85 \\
9697\end{array}$ \\
\hline $\begin{array}{l}\text { Euro } \\
\text { exchange rate, } \\
\text { rub. }\end{array}$ & 3.4 & $\begin{aligned} & 78 \\
.7 & \end{aligned}$ & $00^{70 .}$ & 00 & 00 \\
\hline
\end{tabular}




\begin{tabular}{|c|c|c|c|c|c|}
\hline $\begin{array}{l}\text { Intere } \\
\text { st payments on } \\
\text { a loan } \\
\text { denominated } \\
\text { in foreign } \\
\text { currency } \\
\text { issued for the } \\
\text { construction of } \\
\text { an investment } \\
\text { asset }\end{array}$ & $\mathrm{X}$ & $\mathrm{X}$ & $547^{-55}$ & $927^{-57}$ & $785^{-50}$ \\
\hline $\begin{array}{l}\text { due to } \\
\text { the } \\
\text { acquisition, } \\
\text { production, } \\
\text { modernization, } \\
\text { reconstruction, } \\
\text { and } \\
\text { preparation of } \\
\text { non-current } \\
\text { assets for the } \\
\text { use }\end{array}$ & $\begin{array}{r}7 \\
714816\end{array}$ & $\begin{array}{r}34 \\
828913\end{array}$ & $\begin{array}{r}-18 \\
283699\end{array}$ & $\begin{array}{r}-25 \\
004771\end{array}$ & $\begin{array}{r}-21 \\
358755\end{array}$ \\
\hline $\begin{array}{l}\text { in } \\
\text { connection } \\
\text { with the } \\
\text { acquisition of } \\
\text { shares of other } \\
\text { organizations } \\
\text { (shares) }\end{array}$ & 0 & 6504 & 944678 & 858557 & 529403 \\
\hline $\begin{array}{l}\text { in } \\
\text { connection } \\
\text { with the }\end{array}$ & 77 & $\begin{array}{r}21 \\
625254\end{array}$ & $\begin{array}{r}-17 \\
875403\end{array}$ & $\begin{array}{r}-13 \\
571427\end{array}$ & $\begin{array}{r}-13 \\
764947\end{array}$ \\
\hline
\end{tabular}




\begin{tabular}{|c|c|c|c|c|c|}
\hline $\begin{array}{l}\text { acquisition of } \\
\text { debt securities } \\
\text { (rights to } \\
\text { claim funds to } \\
\text { other parties), } \\
\text { loans to others }\end{array}$ & & & & & \\
\hline $\begin{array}{l}\text { Cash } \\
\text { flow balance } \\
\text { from other } \\
\text { investment } \\
\text { activities }\end{array}$ & $\mathrm{X}$ & $\mathrm{X}$ & $\begin{array}{r}83 \\
324765\end{array}$ & $\begin{array}{r}39 \\
586519\end{array}$ & $\begin{array}{r}36 \\
922095\end{array}$ \\
\hline $\begin{array}{l}\text { Cash } \\
\text { flow balance } \\
\text { from } \\
\text { investment } \\
\text { operations }\end{array}$ & $\mathrm{X}$ & $X$ & $\begin{array}{r}50 \\
128532\end{array}$ & $\begin{array}{r}5 \\
864053\end{array}$ & $\begin{array}{r}8 \\
529195\end{array}$ \\
\hline
\end{tabular}

When building a model, special attention should be paid to the movement of borrowed capital. Interest payments on a foreign currency loan are reflected in the investment activities of the company, and the repayment of the investment loan is carried out in equal monthly installments in the form of an annuity, determined by the scheme for the contribution to debt amortization.

The financial activities of the company, presented in Table 3, include cash inflows as a result of obtaining loans, as well as cash outflows associated with the repayment of debts on previously received loans, as well as accrued dividends.

Table 3:Financial activity of the company

\begin{tabular}{|r|r|r|}
\hline Indicator & Variation range & Simulation experiments \\
\hline
\end{tabular}




\begin{tabular}{|c|c|c|c|c|c|}
\hline & $\begin{array}{ll} & \mathrm{mi} \\
\mathrm{n} . & \end{array}$ & $\begin{array}{l}\text { ma } \\
\mathrm{x} .\end{array}$ & 1 & 2 & 00 \\
\hline g borrowin & 0 & $\begin{array}{r}36 \\
753900\end{array}$ & $\begin{array}{r}2 \\
7848497\end{array}$ & $\begin{array}{r}2 \\
0117041\end{array}$ & $\begin{array}{r}16 \\
972065\end{array}$ \\
\hline $\begin{array}{l}\text { Repaym } \\
\text { ent of principal } \\
\text { debt on a loan } \\
\text { denominated in } \\
\text { foreign currency } \\
\text { issued for the } \\
\text { construction of an } \\
\text { investment asset }\end{array}$ & $\mathrm{X}$ & $\mathrm{X}$ & $\begin{array}{c}58908 \\
883\end{array}$ & $\begin{array}{c}60522 \\
825\end{array}$ & $\begin{array}{r}-58 \\
908883\end{array}$ \\
\hline $\begin{array}{l}\text { payment } \\
\text { of dividends and } \\
\text { other payments } \\
\text { for the } \\
\text { distribution of } \\
\text { profits to owners } \\
\text { (participants) }\end{array}$ & 6 & $\begin{array}{r}7 \\
926791\end{array}$ & 2392699 & 2678267 & $\begin{array}{r}-3 \\
377347^{-3}\end{array}$ \\
\hline $\begin{array}{l}\text { Cash } \\
\text { flow balance } \\
\text { from other } \\
\text { financial } \\
\text { transactions }\end{array}$ & 0 & 1773 & 431144 & $3411^{-}$ & 304464 \\
\hline $\begin{array}{l}\text { Cash } \\
\text { flow balance } \\
\text { from financial } \\
\text { transactions }\end{array}$ & $X$ & $\mathrm{X}$ & $\begin{array}{c}- \\
33884 \\
229\end{array}$ & $\begin{array}{c}- \\
43425 \\
229\end{array}$ & $\begin{array}{r}-45 \\
618629\end{array}$ \\
\hline
\end{tabular}

The final balance is determined by the decrease in the volume of cash receipts from current, investment, and financial activities by the amount of 
related payments and acts as the basis for

calculating the cash balance at the end of

the forecasted period.

Table 4: Cash balance at the end of the period, thousand rubles

\begin{tabular}{|c|c|c|c|c|c|}
\hline \multirow{2}{*}{$\begin{array}{l}\text { Indicat } \\
\text { or }\end{array}$} & \multicolumn{2}{|c|}{ Variation range } & \multicolumn{3}{|c|}{ Simulation experiments } \\
\hline & $\begin{array}{ll} & \text { mi } \\
\text { n. } & \end{array}$ & $\begin{array}{l}\text { ma } \\
\text { x. }\end{array}$ & 1 & 2 & $\begin{array}{ll} & 10 \\
00 & \end{array}$ \\
\hline $\begin{array}{l}\text { Cash } \\
\text { flow balance } \\
\text { for the } \\
\text { reporting } \\
\text { period }\end{array}$ & $\mathrm{X}$ & $\mathrm{X}$ & $\begin{array}{r}5 \\
8381541\end{array}$ & $\begin{array}{r}83 \\
211153\end{array}$ & $\begin{array}{r}-64 \\
906951\end{array}$ \\
\hline $\begin{array}{l}\text { Balanc } \\
\text { e of cash and } \\
\text { cash } \\
\text { equivalents at } \\
\text { the end of the } \\
\text { reporting } \\
\text { period }\end{array}$ & $\mathrm{X}$ & $\mathrm{X}$ & $\begin{array}{r}6 \\
6672501\end{array}$ & $\begin{array}{r}91 \\
502113\end{array}$ & $\begin{array}{r}-56 \\
615991\end{array}$ \\
\hline $\begin{array}{l}\text { Cash } \\
\text { flow adequacy } \\
\text { ratio }\end{array}$ & $\mathrm{X}$ & $\mathrm{X}$ & 25,12 & 08 & $\begin{array}{rr} & 0,1 \\
9 & \end{array}$ \\
\hline
\end{tabular}

At the final stage of the study, an analysis of the results was carried out using an array of indicators of descriptive statistics. Evaluation of the average values, their scatter, determination of the boundaries of the change in the resulting indicator, as well as an independent interpretation of the distribution of experiments with a positive or negative cash balance made it possible to formulate the main conclusions about the results of the study 


\section{Results And Discussion}

It is advisable to generalize the array of forecast data obtained as a result of the experiments using the indicators of statistical evaluation, detailing it according to the three indicated types of activity (Table 5).

Table 5: Descriptive statistics of simulation results by types of activity

\begin{tabular}{|c|c|c|c|c|}
\hline \multirow[b]{2}{*}{ Indicators } & \multicolumn{3}{|c|}{ Cash flow balance from } & \multirow{2}{*}{$\begin{array}{l}\text { Cash } \\
\text { balance } \\
\text { and cash } \\
\text { equivalents } \\
\text { as of the end } \\
\text { of the } \\
\text { reporting } \\
\text { period }\end{array}$} \\
\hline & $\begin{array}{l}\text { curre } \\
\text { nt } \\
\text { transactions }\end{array}$ & $\begin{array}{l}\text { inves } \\
\text { tment } \\
\text { transactions }\end{array}$ & $\begin{array}{c}\text { fina } \\
\text { ncial } \\
\text { transactions }\end{array}$ & \\
\hline Average & $\begin{array}{r}16 \\
734917\end{array}$ & $\begin{array}{r}-17 \\
352607\end{array}$ & $\begin{array}{r}-42 \\
874381\end{array}$ & 201111 \\
\hline $\begin{array}{l}\text { Standard } \\
\text { deviation }\end{array}$ & $\begin{array}{r}47 \\
329520\end{array}$ & $\begin{array}{r}49 \\
029759\end{array}$ & $\begin{array}{r}11 \\
417915\end{array}$ & $\begin{array}{r}95 \\
649922\end{array}$ \\
\hline $\begin{array}{l}\text { Variation } \\
\text { coefficient }\end{array}$ & $\%$ & $283 \%$ & $27 \%$ & $272 \%$ \\
\hline Minimum & $\begin{array}{r}-95 \\
277337\end{array}$ & $\begin{array}{rl} & -153 \\
431 & 060\end{array}$ & $\begin{array}{r}-67 \\
970121\end{array}$ & $\begin{array}{r}-270 \\
889972\end{array}$ \\
\hline Maximum & $\begin{array}{r}148 \\
425067\end{array}$ & $\begin{array}{r}142 \\
173583\end{array}$ & $\begin{array}{r}-16 \\
431799\end{array}$ & $\begin{array}{r}265 \\
613315\end{array}$ \\
\hline
\end{tabular}

The data in the table indicate that the cash balance at the end of the period ranges from -270.9 billion rubles to 265.6 billion rubles. This allows us to conclude about the threat to the deterioration of the financial stability of the company due to significant volatility of cash flows under the influence of a set of factors of internal and external environment.

In order to improve the quality of a meaningful interpretation of the 
results obtained, it is supposed to conduct an independent statistical assessment and visual presentation of the results of experiments that demonstrated a positive and negative level of cash balance at the end of the forecast period. In particular, it is advisable to separately characterize the array of profitable and unprofitable experiments from the perspective of estimating the probability of profit (loss), determining the average amount of profit (loss) from the experiment, calculating the coefficient of variation reflecting the relative scatter of the values of the main array of profitable (unprofitable) experiments from the average value.

Table 6 shows that the proportion of positive experiments was only $38 \%$ with an average cash balance of 64 billion rubles, while the average negative cash balance was 95.8 billion rubles.

Table 6.:Descriptive statistics of cash balances

\begin{tabular}{|l|c|}
\hline \multicolumn{1}{|c|}{ Indicator } & Value \\
\hline 1. Positive experiments & 379 \\
\hline number & $38 \%$ \\
\hline 1.2. Proportion & 64071623.61 \\
\hline 1.3. average positive cash balance & 621 \\
\hline 2. Negative experiments & $62 \%$ \\
\hline 2.1. quantity & -95787852.11 \\
\hline 2.2. specific gravity & \\
\hline 2.3. average negative cash balance & \\
\hline
\end{tabular}

Figure 1 shows a histogram of the frequency distribution of positive experiments. The largest number of experiments in this group ranges from 17.4 billion rubles to 29.8 billion rubles. 
Statistics of positive experiments

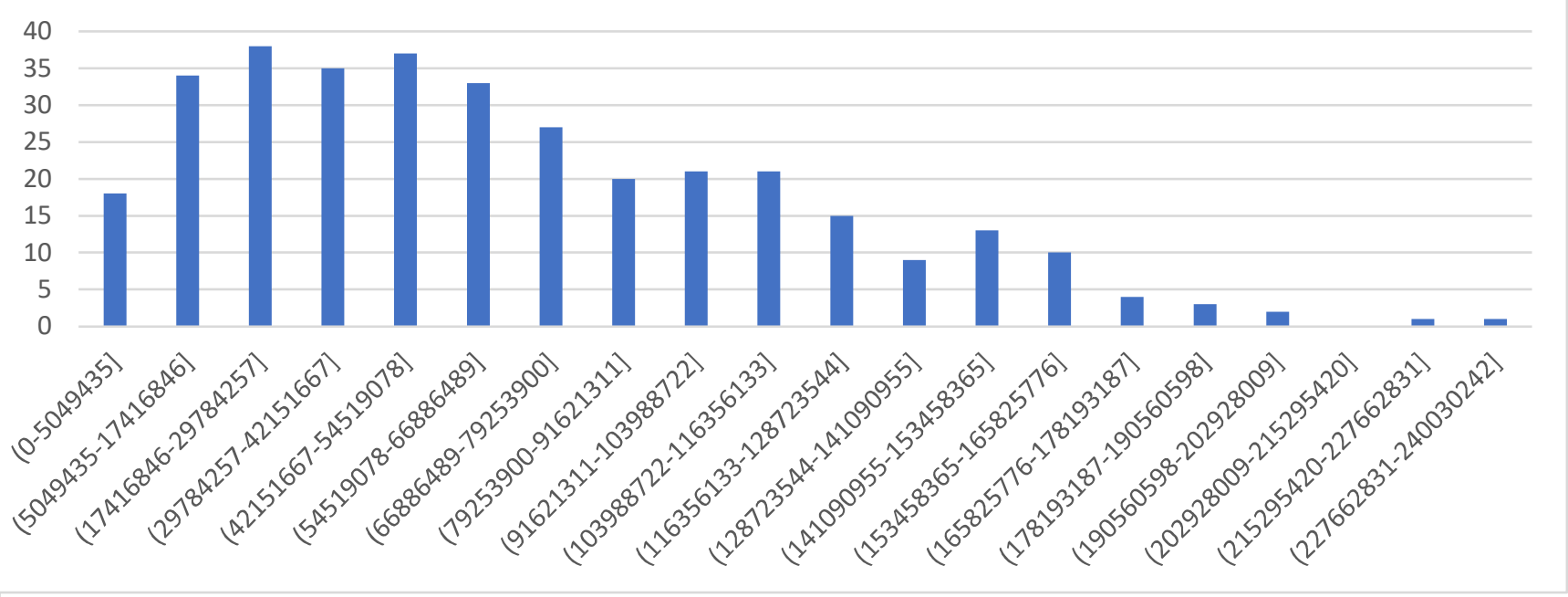

Figure 1. Distribution of positive cash balances

Negative experiments were the range from -27.9 billion rubles to separately analyzed. The highest weight 16.9 billion rubles.

of negative experiments corresponds to

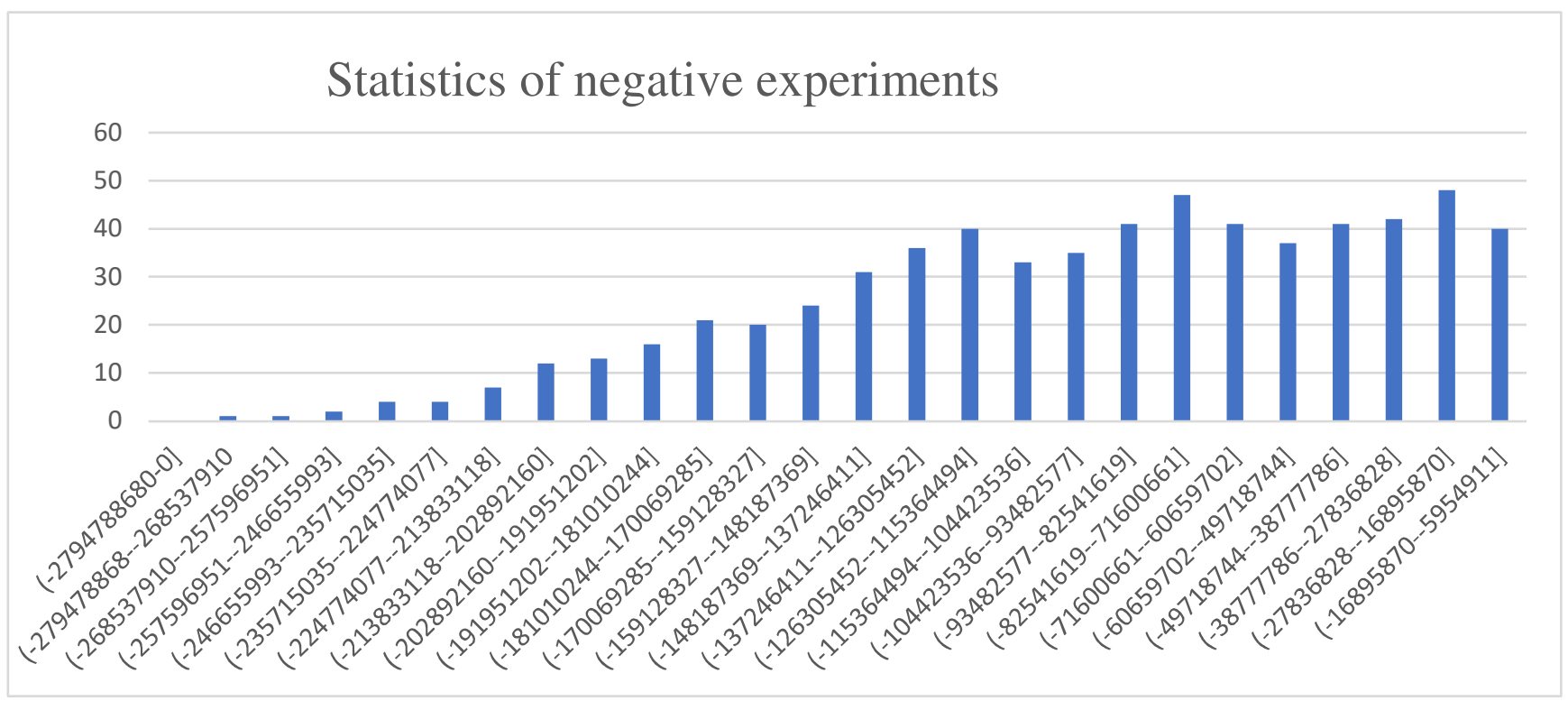

Figure 2. Distribution of negative cash balances 


\section{Summary}

The implementation of approaches to scenario forecasting of cash flows of the company, proposed in the framework of this simulation model, allows us to assess the prospects for changes in the financial condition of the organization and make timely adjustments to the management policy of its current, financial and investment activities. The model for the prospective assessment of cash flows serves as an information basis for preventive regulation aimed at effectively counteracting the factors of uncertainty and risk of the external environment of the enterprise.

\section{Conclusion}

The model was tested by the authors on the basis of empirical data from a large petrochemical company, however, the universal nature of the conceptual framework of the approach does not limit the prospects for its application, taking into account the specifics of alternative types of economic activity. The ability to quickly adjust the boundaries of the range of variation of dependent variables, taking into account changes in the operating conditions of the company, opens up opportunities for continuous scenario forecasting of cash flows in the financial stability management system of an economic entity.

\section{Acknowledgments}

The work is performed according to the Russian Government Program of Competitive Growth of Kazan Federal University.

\section{References}

Abad, P., Benito, S., López, C. (2014) A comprehensive review of Value at Risk methodologies. Spanish Review of Financial Economics. 12(1), pp. 15-32.

Chernavsky K. 2010 Events and trends control in diagnostics of financial capacity of transportation companies. The Journal of Alternative Investments. 13 (1), pp. 41-54.

Barth, ME, Cram, DP, Nelson, KK (2001). Accruals and the prediction of future cash flows. Accounting review. 76(1) pp. 27-58 
Basak, S., Shapiro, A. 2001 Value-atrisk-based risk management: Optimal policies and asset prices. Review of Financial Studies. 14. pp. 371-405.

Eppen, Gary D., Matin, R. Kipp, Schrage, Linus (1989) Scenario approach to capacity planning. Operations Research. 37(4). pp. 517527.

Harrison, J.R., Lin, Z., Carroll, G.R., Carley, K.M. (2007) Simulation modeling in organizational and management research. Academy of Management Review. 32(4), pp. 12291245.

Hendry, D.F. (1984) Monte carlo experimentation in econometrics. Handbook of Econometrics 2, pp. 937976.

Huss, W.R., Honton E. J. (1987) Scenario planning -What style should you use? Long Range Planning. 20(4). pp. 21-29.

SPARK [Electronic resource]: A professional market and company analysis system. Access mode:

http://www.spark-interfax.ru

Interfax: a corporate information

disclosure center. [Electronic resource].

Access mode: https://www.e-

disclosure.ru 